\title{
China's Digital Silk Road: The Loss for Indonesia
}

\author{
${ }^{1}$ Nanda Blestri Jasuma, ${ }^{2}$ Arie Kusuma Paksi \\ ${ }^{1,2}$ Departement of International Relations, Faculty of Social and Political Science, \\ Universitas Muhammadiyah Yogyakarta - Indonesia \\ Email: nanda.blestri.isip18@mail.umy.ac.id
}

\begin{abstract}
One of China's great projects in the current digital era, namely the Digital Silk Road (DSR) project, merits an examination from a Gramscian lens. While liberals are talking about how this project can beneficially the partner's country, Gramsci's thought can provide the other perspective in understanding how this project can give unexpected costs for the partner country. As the biggest market in Southeast Asia's country, Indonesia is worth the attention related to this issue as this country has become one of the strategic partners of China's DSR. However, DSR is offering both economic benefits and multi-faceted costs simultaneously for Indonesia. Hence, this study argues that the DSR project, in Gramsci lens, is giving a push for China to spread its hegemony and take over the domination in the Indonesian economy. This study is supported by the qualitative research method with the data is collected through secondary data and literature review.
\end{abstract}

Keywords: DSR, China, Indonesia, Hegemony

\begin{abstract}
Abstrak
Salah satu proyek besar China di era digital saat ini, yaitu proyek Digital Silk Road (DSR), patut ditelaah dari pandangan Gramscian. Sementara kaum liberal berbicara tentang bagaimana proyek ini dapat menguntungkan negara mitra, pemikiran Gramsci dapat memberikan perspektif lain dalam memahami bagaimana proyek ini dapat memberikan kerugian yang tak terduga bagi negara mitra. Sebagai pasar terbesar di negara Asia Tenggara, Indonesia patut mendapat perhatian terkait isu ini karena negara ini telah menjadi salah satu mitra strategis DSR China. Namun, DSR secara bersamaan menawarkan manfaat ekonomi dan kerugian di berbagai aspek untuk Indonesia. Oleh karena itu, penelitian ini berpendapat bahwa proyek DSR, dalam kacamata Gramsci, mendorong China untuk menyebarkan hegemoninya dan mengambil alih dominasi ekonomi Indonesia. Penelitian ini didukung dengan metode penelitian kualitatif dengan data dikumpulkan melalui data sekunder dan studi pustaka.
\end{abstract}

Kata kunci: DSR, China, Indonesia, Hegemoni 


\section{INTRODUCTION}

Alongside the launch of the Belt Road Initiative (BRI), the Digital Silk Road (DSR) has been one of the key components of BRI. To successfully run BRI, China tends to build such strategies by introducing the most upto-date and globalized economy cooperation strategy by utilizing the digital platform. Instead of solely reckon on the physical infrastructure strategy, China does not want to miss the chance to promote the economic digitalization cooperation through DSR, which critically aims to expand the Chinese technologies globally. The vast growth of digital utilization in the range of trade has been a worthy consideration for China to compete in the global trade at greater convenience, across borders and supply chains.

The definition of digitalization itself has been posed by many scholars, particularly in international relations studies. As mentioned by Rusakova et al., (2020), digitalization which concerns with the economy, involves digitalization in the economic process, including the development of strategies and plans of the digital economy, the simulation of risks and repercussions of adopting innovations and information and communication technologies, and so on. As a result of globalization and advanced technology, digitalization is worth to be discussed in a broad lens such as politics, society, economy. Digitalization has become prominent in the current era as it affects multifaceted fields in our everyday life. It affects almost all aspects of our life by a revolutionary change in the way people, consumers, and businesses behave, works, and communicate globally (Myovella, et al., 2020).

Further, digitalization even has become the dominant driver in altering our perception of the modern state. Economically, we cannot deny that liberalized market has dominated a global market system. Digitalization has further supported this practice of economy as it offers the advancement in the economic process. For instance, digitalization offers a very effective way of trading through e-commerce, where people can easily buy and sell products and services domestically and internationally. It also provides multiple services such as online lending money service, workforce service, and so on in a convenient way. It in line with the definition of digital economy from Mari Pangestu (2019) that is worth to be mentioned in this regard,

"Digital economy is the process of converting "things" in the physical world to a piece of information, a. digital representation - a tara point. It covers three aspects of the process; Production and Market (in this 
aspect, there is a shift from physical to virtual), Transaction (as same as the previous aspect), and Economic System (in this aspect, there is a shift from corporate-centric to crowd-centric)". Mari Pangestu in Hong Siew Ching Speaker Series 2019.

In international relations, the digital economy now takes a critical role in conducting economic cooperation among nations. As has been mentioned by Pangestu, that digital disruption has been around as a part of our life.

As one of ASEAN members, Indonesia has become the strategic partner for China to boost the digital economy cooperation. Currently, Indonesia is a country with an emerging economy with significant potential economic development in Southeast Asia. Indonesia's existing market condition, which is worth $\$ 1$ trillion of GDP and $\$ 7.1$ billion mobile commerce market size (J.P. Morgan, 2019), potentially attracts China to run the DSR. Further, the current economic forecast even predicts that the projected market volume of Indonesia in 2021, worth US\$1,260,539 million, the revenue is mostly generated in China (Statista, 2021). DSR, in particular, not only targets the potential of Indonesian market volume and consumer buying but also specifically promotes the use of Chinese technology in Indonesia.
As the data shows that Indonesia is not in the advanced stage of digitalization, it has a huge population that is considered the most active digital user globally and vigorous startup dynamics (Das, et al., 2016). Hence, China undoubtedly considers Indonesia to become its strategic partner in promoting its technologies.

However, the fact that Indonesia might harvest economic benefits from the DSR project cannot be separated from the cost that Indonesia can get. The economic cooperation, particularly in the DSR project, between Indonesia and China is worth of multi-faceted analysis, including politics, economy, and social. It is because the cooperation between both countries involves a digitalization effort that is considered as a new thing in international cooperation terms. As we know, digital media, notably for economic activities, provides borderless features with a very minimum barrier of trade. This, of course, will accelerate transnational connectivity. In international relations studies, the transnational connection certainly includes a comprehensive and complex coherence. In terms of DSR, we cannot solely see this as the usual economic cooperation as digital platforms become dominant in an emerging market. This study examines the motive of China in implementing DSR in Indonesia and finds out the 
implications of this program for both countries. This study includes three sections of discussions: the first one outlines how China shapes the DSR framework, the second will discuss the implications of DSR to China, and the last section will discuss the implications of DSR to Indonesia.

\section{LITERATURE REVIEW}

Economic cooperation among countries has been vocal in international relations studies. Vigorously promoted by liberals, mutual cooperation, in economic terms, will harvest the best outcome through the liberalized economy system (Milner, 2005). However, the liberalized market directly leverages the monopoly system in the market, in which only particular entities play a prominent role. Although, as has been witnessed for decades, the US, together with its Western-like model economy, has been favored by the world, China is currently representing the antipole over this US-centric economy (Tiberghien, 2020).

In line with the aims to be a new leader in the global market, China has issued such initiative programs to obtain its goal. BRI plays a prominent role in supporting Xi's ambition to be in control of the global market by involving the DSR as its key component (LY, 2020). DSR implementation would increase economic growth, improve economic development efficiency, create jobs, and improve people's well-being. It also creates new possibilities for incorporating the notion of long-term economic growth (Lazanyuk \& Revinova, 2019). Starting with the intention of enhancing the domestic economic development of China, DSR is the initiative of Xi's administration that is prioritizing the integration of communication services and information sharing (LY, 2020). Xiang Gao (2020).

By engaging with the partner countries, DSR is far-reaching the overseas market, including Asia, Europe, Africa, and America. Southeast Asia, particularly ASEAN, has been a strategic partner for DSR as its emerging market has attracted global trade. According to Bhagawati (2018), in his article titled "The Pitfalls of China's "Digital Silk Road" in Southeast Asia", China has increased the reach of its domestic satellite navigation system to include all nations along the BRI, including ASEAN members. By 2020, it would like to have a constellation of 35 satellites to construct a "space information corridor" and eliminate its dependency on the US GPS. Further, as the emerging markets, the opportunity has been seen in the ASEAN countries to expand the goal of DSR. This ambition is keen to the 
realization of 'The 2020 ASEANChina Digital Economy Conference' that held in Chengdu as evidence of the ASEAN-China commitment to improving its digital economy cooperation.

Some scholars are actively proposing their studies on how DSR affects the ASEAN countries. For instance, Stec (2018) has exposed briefly how the DSR IT project is successful in providing the automation of customs procedures in Malaysia, which then followed by the formation of 'Digital Free Trade Zone' links China and Malaysia (Chandran, 2018). While in Singapore, the implications of DSR are more pronounced. Giant. Companies from China are massively investing and acquiring Singapore's ecommerce companies (Bhagawati, 2018). In the Philippines, this project is to leverage the smart city model that has been intensely established in China (Chia, 2018). Under BRI and DSR as its driving component, Manila has been the place for China to implement the largest infrastructure project, namely New Manila Bay - City of Pearl'.

The existence of Indonesia as the emerging market and the most potential market in ASEAN in regard to DSR is seldom discussed by scholars. The majority focuses on the implications of DSR to ASEAN in broad, or implications of DSR to particular countries, which enhances the digital infrastructure project such as the Philippines (Chia, 2018). Indonesia shall not be undermined as the subject of discussion as the prospect partner of DSR in implementing China's digital economy strategy. In this sense, the use of Gramsci thinking of hegemony also needs further exploration as this way of thinking offers us a more specific intention that DSR projects have.

\section{THEORETICAL FRAMEWORK}

In accordance with the purpose of the study, the Gramscian perspective in understanding the hegemony concept is adopted. The main purpose of Gramsci's thought is to understand the spread of hegemony from class domination throughout society (Gramsci, 1971). Gramsci makes the concept of hegemony becomes crystal clear, which said that it refers to political leadership founded on the consent of the led, consent that is secured by the spread and popularization of the ruling class's world view (Bates, 1975). Hegemony also tends to establish a historical bloc, which comes from converting the dominant way of life and thought of a certain class (Woolcock, 1985). It is in line with what Gramsci has emphasized the form of historical bloc after the certain class successfully 
acquires domination (Gramsci, 1971). In a hegemonic system, the historical condition is important for a class to acquire hegemony over others (Ibid., p. 204). Further, the successful hegemony is the one that can construct a "collective nation-popular will" (Ibid., p. 206), which means that the dominant class can represent the national interest. Therefore, hegemony can construct global norms and expectations about political, economic interactions (Morgan, 2002).

However, many misunderstandings exist in following the definition of hegemony itself. The critical point of hegemony is often adopted from the realist perspective, which focuses solely on power. This thought defines hegemony as the result of acquiring active domination. Realists' analysis of the concept of hegemony leads to the state-centric analysis. Instead of only limited to state-centric, Gramsci exercises the broader concept of hegemony. Hegemony, according to Gramsci, is not the relations of domination with the use of power but the relations of consent with the use of political and ideology leadership. Those measures are a matter for certain groups who want to achieve hegemony (Patria \& Arief, 1999, pp. 118-119). In addition, Gramsci argues that hegemony is about how to organize the consensus or mutual agreement.
Refer to the theory, the idea of economic digitalization by China in Indonesia, through DSR, is a form of strategy to achieve economic hegemony, especially in the ASEAN region. DSR, through BRI, is a mutual agreement achieved by both parties and examined without any coercion. This ambitious project of China leads to the hegemony of economic control over targeted countries in China's 'silk road'. However, the explanation of how China conducting such means to obtain the hegemony will be explored in-depth in the following discussion.

\section{METHODOLOGY}

This study utilizes the China Digital Silk Road as a case to investigate. Using a qualitative approach, this study contains secondary data, including library research, as a data collection method. It aims to articulate the related issue to be more specific and have an in-depth analysis.

\section{DISCUSSION}

The BRI has taken a further significant development by committing to the digital turn. This then leads to the creation of DSR. Through DSR, it will make China easily conduct cooperation with the other countries to expand Chinese technologies globally, which ranges 
from telecommunications networks and smart cities to e-commerce, and accomplish the goal of China's new satellite system (Dekker, et al., 2020). In line with the domestic economic development strategy, namely 'Made in China 2025' (Cyrill, 2018), that aims to globalized high-tech China's product and achieve the value-added global sourcing segment, DSR was born to attract the international attention and set out to combine a domestic effort to export Chinese technology created through forceful industrial policies with a larger ambition to improve interoperability and compatibility between Chinese and international technical networks on Chinese criteria (Dekker, et al., 2020). The total amount of investment estimated at US\$79 billion for the digital infrastructure project overseas evidently represents the ambitious project of DSR (Ghiasy \& Krishnamurthy, 2020).

DSR is connecting China's domestic and international interests related to China's technology development simultaneously. At the domestic level, the DSR program aims to prioritize the convenient way for the local enterprises to run the business. The utilization of technology, including the hardware and the software, encourages the Chinese local to promote their business and enhance the relations among business and consumers and vice versa (Ghiasy \& Krishnamurthy, 2021). DSR catalyzes the local enterprises to promote their business by pushing the export amounts of China's products, which is in line with 'Made in China 2025' to make China a technological superpower (Ghiasy \& Krishnamurthy, 2020). Therefore, through DSR, China government strongly encourage the local business to be able producing global level technologies. DSR provides the realization of such policies to promote the local business to blow away its charm in global business. President Xi has been committed to giving extra treats for the local companies with subsidies and credit to easily acquire cutting-edge business (Abe, 2016). This is giving a push the local companies in China to invest in the foreign reputable and strategic companies confidently. In order to attract the world eye over the Chinese technology, DSR offers such interesting economic cooperation with foreign countries, particularly the developing countries that need help to improve their technology. China is exposing itself as the largest trading partner for some developing countries like India (Ghiasy \& Krishnamurthy, 2020), ASEAN countries (Global Times, 2021), and EU countries (BBC News, 2021). China is giving the push to dominate the global economy 
through digitalization at the next level. Not solely usual economic cooperation, DSR offers the various advantages of China's advanced technologies. The partner countries will be able to experience the benefits of advanced technologies, with China as the main driver. Currently, China is massively promoting China's BeiDou satellite with the more affordable cost and more advance in terms of technology and specification compared to the US' technology, BeiDou is successfully being adopted by some Asia countries and Africa (Ghiasy \& Krishnamurthy, 2021). BeiDou has become one example in explaining China's commitment to be at the forefront of advanced AI technologies after Huawei and Xiaomi. China also innovates such platforms to support the run of the digital economy, such as e-commerce, online payment and financial services, and so on (Dekker, et al., 2020). Combining the geopolitical and technology landscape, DSR will be an enormous shift in terms of economic cooperation in the global arena.

In understanding how DSR works broadly, we firstly should analyze the key aspects that DSR takes into account. There are five critical aspects in accordance with DSR (Dekker, et al., 2020) as following: infrastructure (involving telecommunications and AI infrastructure), trade (encouraging ecommerce companies and all-channel online shopping, finance (involving online payment and financial services), people's heart (it is meant to be how this digitalization can attract the critical part of people in their daily activities), and policy (includes China Standards 2025). In the context of its partnership with Indonesia, China is utilizing the infrastructure, trade, and finance aspects in undergoing the mission. In addition, the outstanding amount of consumers' prospects in Indonesia has been a critical factor that makes China keen on the partnership. According to Google e-Conomy SEA 20 Report, Indonesia's Gross Merchandise Value (GMV) is expected to gain US\$ 124 billion in 2025, which is the highest amount among ASEAN countries (See Figure 1). The high rate of internet penetration in Indonesia that has reached $73.7 \%$ in January 2021 (Kemp, 2021) also significantly influences China to implement the DSR project. Considering the potential market in Indonesia has triggered Chinese companies, through DSR, to expand their market to Indonesia. In Indonesia, the DSR project focuses on such things involve: promoting the 5G technology, promoting, acquiring, and investing in the e-commerce and financial technology (fintech) in Indonesia. 
Figure 1. The Digital Economy Values Among ASEAN Countries

SEA Internet economy GMV (US \$_B)

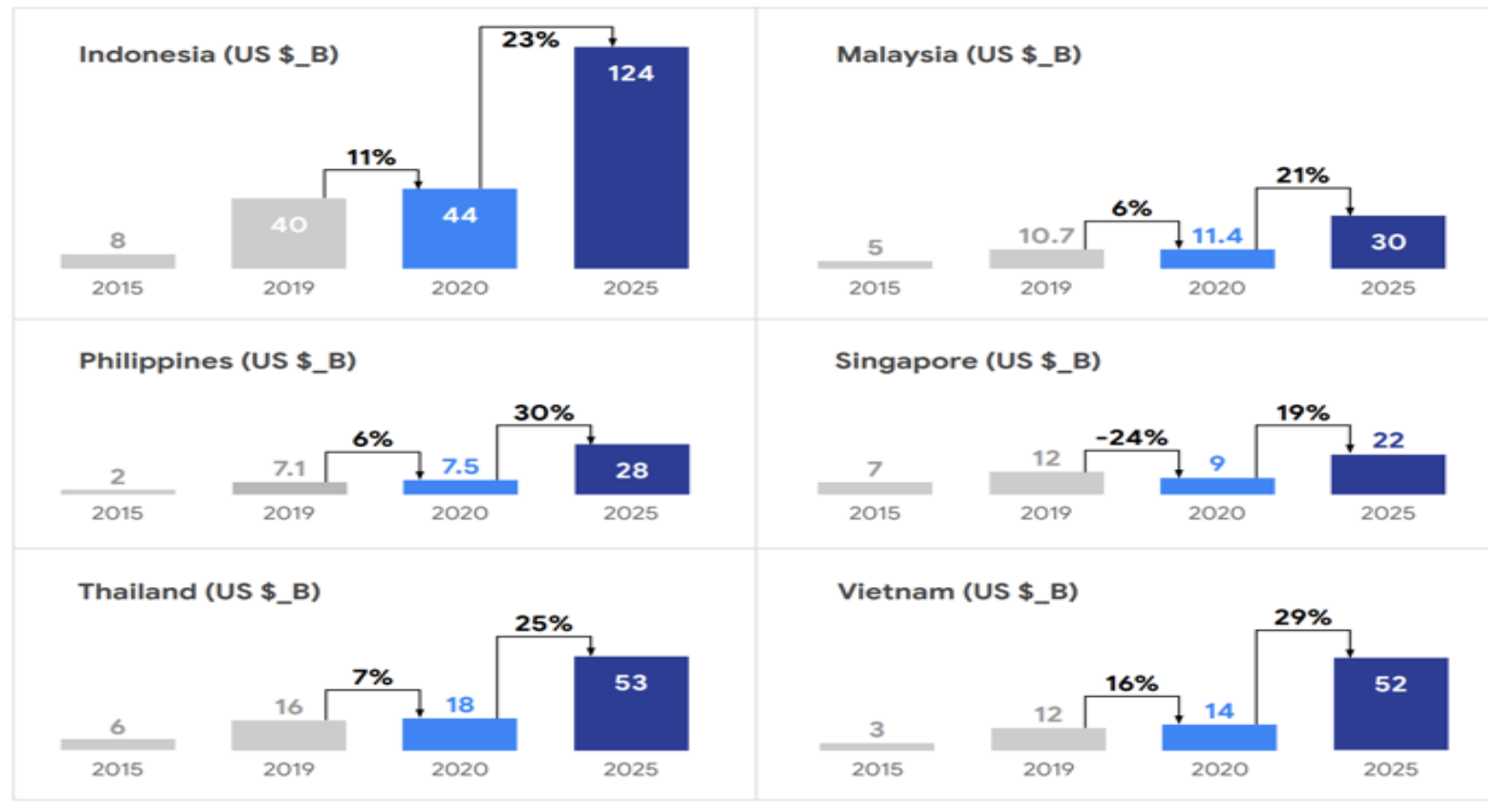

Source: Google, Temasek, Bain 2020

The aforementioned framework of DSR is explicitly explaining the motive of China in initiating the DSR project. As has been mentioned that China would like to achieve the goal of 'Made in China 2025', China later introduced the 'China Standards 2035' policy that is in line with 'Made in China 2025' to globalized China's high technology with China standards. 'China Standards 2035' is emphasizing the use of China standards as the global standards in the global technology industry. In introducing the technologies and the programs of DSR, Xi's administration is committed to this standard. For instance, the warm welcome of developing the $5 \mathrm{G}$ connection has met on a deal between Chinese company Huawei with the Indonesian government. In online platforms like fintech industries, ecommerce, and so on, DSR is aimed to give a significant influence to the partners by investing a large amount of money from Chinese companies-or in some cases, they acquire partners' companies. In Indonesia, for instance, many Chinese giant companies, like Alibaba Group, actively forge up the investment in operating e-commerce in Indonesia, such as Tokopedia with $28.3 \%$ share ownership (Kusuma, 2020) and in fintech such as DANA that is fully backed by Ant Financial (Hakim, 2020). 


\section{Implications for China}

As such, the intention of China is apparently obvious that China aims to be in control over the global information and communications technology (ICT) through constructing the digital infrastructure globally (Pointe Bello, 2019). In addition, economic digitalization also occurs as support to shape the globalized China-based digital economy. Both intentions will generate China's hegemony shoots in the economy. China companies in the global market, particularly in the emerging market, and through DSR, will shape the dominance of China companies and turn China into the market setter.

The development of 5G technology, for instance, is currently developed in China through Huawei as China's giant telecom company and it is successfully positioning China as one of the leading countries that succeed in building and deploying this new kind of technology. It has been an attractive offer for China in providing affordable technology comparing to western products (Rakhmat \& Purnama, 2021). Due to the high demand of Indonesian citizens in participating in the internet connectivity, Indonesia definitely needs $5 \mathrm{G}$ technology to improve the quality of internet connection, which is currently still in the low rank among
ASEAN countries (The ASEAN Post, 2019). However, the implementation of $5 \mathrm{G}$ in Indonesia, of course, will have more benefits to China compares to Indonesia as it is worth of US\$27 billion project (Yuniar, 2020).

The unfair advantage might rise as China is compiling the data information of Indonesian citizens by utilizing its technology. Some have said that Chinese technologies allow its government to surveil other nations or help the particular partner's government spy on their people. Out of security context, China will take advantage of the conducted deal of $5 \mathrm{G}$ development in Indonesia by offering China-based technology only. To develop 5G, there will be such additional technologies to support the installation, whether like it or not, Indonesia must buy all the technological cooperation from China. Further, to make this technology is adaptive for Indonesian, China provides the training for 100,000 Indonesians to master the technologyrelated fields, according to the signed MOU between both countries (Yuniar, 2020). It might slightly give fresh air for Indonesia, yet we have to aware of the future benefits that China still keeps. By asking China's help to train Indonesians, the China-based standard of technology will be prioritized in Indonesian's mind, which later gives rise to 'Chinanization' like what we 
have drawn from 'Westernization' for decades. Through Huawei, China can successfully acquire the hegemony in Indonesia, which is such a benchmark for China in maintaining its superpower feature in the emerging market.

Related to e-commerce and fintech, China is also showing off its soft canine in Indonesia's market. The rising number of online shoppers in Indonesia, which is worth 20 million in 2017 and expected to grow to 65 million in 2022, according to Statista, has generated China's intention. China has stepped up its effort to give influence in Indonesian e-commerce boom. China is well known as one of the biggest investors for Indonesian ecommerce. As a giant digital company, Alibaba has backed big e-commerce companies in Indonesia such as Tokopedia, Lazada, AliExpress (CNBC Indonesia, 2019). The other China company like Tencent also massively invests in Shopee, one of the big e-commerce operates in Indonesia. The influence of China in its acquisition and investment activity in Indonesia generates a significant influence in many aspects, which mostly benefits China. First, look at how these e-commerce selling pattern shows the domination of Chinese products are unavoidable as China can effectively distribute its products in acquired in invested Indonesian e- commerce. This has been seen from the data that said import products are massively marketed in Indonesian ecommerce that is valued at $90 \%$ of overall products sold in the marketplace (Iswanto, 2021). The price offered from such Chinese products in Indonesian e-commerce is also underpriced. Thus, no wonder if Chinese products sold more than Indonesian products.

In the fintech sector, China is committed to offering mobile payment services in Indonesia. Eagering to be in control in Indonesian fintech, China firms have invested in such Indonesian fintech companies as Gopay, OVO, and DANA. Not only making efficiency in payment and investment, but Chinese fintech companies also offer easiness in the lending sector. As many Indonesians are not connected in the banking sector and $60 \%$ of the citizens work in the informal sector, they face difficulty lending loans. Therefore, the emergence of Chinese fintech companies is trying to open the access for debt simplicity. With no complex documents needed, the borrowers can lend money from this digital feature of fintech. As a result, the easiness gives a push to the borrowers to guarantee their relatives' data as the pawn for the loans. This has triggered protests from people whose data is collected as the debtor's relatives because they often receive 
calls from the fintech company regarding the debtor's failing to pay. In some cases, the company also has access to reach out to the borrower's contact list without consent (Suleiman, 2019). China has successfully to be in control over data access in the fintech sector. This collected data can later be utilized by China to have control over the data abuse.

China as the major supporter of the Indonesian digital economy, has proven its commitment through such a DSR program. By investing and acquiring such e-commerce and fintech companies, China has strategic access to spread its influence in Indonesia. As a result, the control and new emerging hegemony of China have spilled out. In technology terms, like developing 5G technology, China is now the leading and largest partner for Indonesia. Within the same notion and background as the Asian, huge population, and developing countries, the closer tie between Indonesia and China is unavoidable.

\section{Implications for Indonesia}

The fact that DSR implementation, under BRI, in Indonesia is apparently giving Indonesia more costs than benefits as China has gained the investment worth of US\$ 5 trillion in 2019 (Sinintya \& Sebayang, 2019) while Indonesia experiences the increase of Indonesia's debt to China by US $\$ 17.75$ billion in 2019 (Purnama, 2020). The fruitful advantages might have been seen, but the other side and costs are often neglected. The dependency on China is currently appearing in the country. Let us figure out how in technology involving economic digitalization terms, Indonesia needs support almost in many aspects involving human resources training, technology procurement, and technology financing.

Indonesia currently cannot stand alone in facing economic digitalization as it has many flaws and a lack of technology issues. For instance, in Indonesia's emerging e-commerce boom that still lacks experience, accompaniment is needed. Of course, the predicted answer comes up, the official advisor chosen by the government is Jack Ma, the founder of Alibaba. Taken the chance from Indonesia's Minister of Communication and Information, Jack Ma has elected to be an ecommerce advisor in Indonesia that focuses on helping the development of Indonesian e-commerce. Being evolved in the government, Jack Ma will take a step to give such guidance for the Indonesian government, including how to escalate the quality of the human resources and help the improvement in Indonesian policy, 
thus fitting in the current development of e-commerce (Widiartanto, 2017). The involvement of Chinese enterprises in the government to lead the roadmap of a particular economic goal has indicated the dependency that occurs in Indonesia. Figuring China as the role model in emerging ecommerce, Indonesia has a notable trust in China. We cannot deny the possibility that might come when the involvement of a particular party in the policy decision-making process is a sign of an agenda-setting process (Birkland, 2007). According to Birkland, when the society or political institutions do not have the capabilities to gain solutions over particular issues, the agenda-setting from particularly involved parties in the process occurs. In this regard, Jack Ma's existence represents the aim of China to be in control over the economic system in Indonesia, particularly in handling the development of e-commerce. Determining such policies to be implemented in the system might help China to accelerate its effort in acquiring the hegemony in the economy over Indonesia. Not only as the market setter, but China is also potentially turning itself to be involved in the policymaking in Indonesia.

Focusing more on the economic side, we cannot deny the acquisition of e-commerce in Indonesia by Chinese firms has resulted in unfair competition between local enterprises and Chinese enterprises. As has been known that Chinese products are massively sold in the Indonesian marketplace, the local products are left behind. Valued only up to $5 \%$ in ecommerce, the proportion of Small and Medium Enterprises (SMEs) products is problematic for the ecommerce industry in Indonesia. The consumers' preference over the imported products is commonly caused by the low price offered by them, particularly the products from China. It is representing the lack of Indonesia in handling the domination of China in the economic field. With the same potential as the large market, both countries should show similar progress as well. Unfortunately, the domination of China is inevitable. As the market setter, China knows better how to compete in the market. Therefore, the decision to invest and acquire e-commerce in Indonesia is the best decision for China to unleash its domination and hegemony.

\section{CONCLUSION}

DSR is formed as the accelerating tool for China to maintain its hegemony globally. Therefore, the Gramsci lens should be taken into account as the way of thinking in responding to the DSR project in Indonesia. Indonesia cannot solely view this economic cooperation as 
fully beneficial for the people, but the other invisible cost must be considered. Security, market competition, and dependency are the three areas in that Indonesia did not take it as a big deal. In the future, the policymaker should not pay attention to the economic benefits such as the enormous amount of investment and technology development. The critical point that Gramsci's perspective tries to examine in this case is that the domination that is taken over by China will be a key concern. Thus, Indonesia should start the action by its shoes such as learning how to develop technology aspect, give push into the development of human resources and enterprises, to ease the establishing hegemony of China.

\section{REFERENCES}

Abe, T. (2016) Backed by their government, Chinese companies splash out abroad (Online). Available at: https://asia.nikkei.com/Business/Bac ked-by-their-government-Chinesecompanies-splash-out-abroad (Accessed: 31 May 2021).

Bates, T. R. (1975) "Gramsci and the Theory of Hegemony". Journal of the History of Ideas, April, 36(2), pp. 351366.

BBC News. (2021) China overtakes US as EU's biggest trading partner (Online). Available at: https://www.bbc.com/news/busines s-56093378 (Accessed 31 May 2021).
Bhagawati, J. (2018) "The Pitfalls of China's "Digital Silk Road" in Southeast Asia". e, December, 1(2), pp. 6-14.

Birkland, T. A. (2007) Agenda Setting in Public Policy. In: Fischer, Frank, G. J. Miller \& M. S. Sidney, eds. Public Policy Analysis: Theory, Politics, and Methods. s.l.:CRC Press.

Chandran, N. (2018) Alibaba's 'Digital Free Trade Zone' has some worried about China links to Malaysia (Online). Available at: https://www.cnbc.com/2018/02/12/ concerns-over-alibaba-led-digital-freetrade-zone-in-malaysia.html (Accessed: 2 June 2021).

Chia, J. (2018) Five Chinese smart cities leading the way (Online). Available at: https://govinsider.asia/security/fivechinese-smart-cities-leading-way/ (Accessed: 2 June 2021).

CNBC Indonesia (2019) Investor China Penyokong E-Commerce Indonesia (Online). Available at: https://www.cnbcindonesia.com/tec h/20190516130811-3972916/investor-china-penyokong-ecommerce-indonesia (Accessed: 4 June 2021).

Cyrill, M. (2018) What is Made in China 2025 and Why Has it Made the World So Nervous? (Online). Available at: https://www.chinabriefing.com/news/made-in-china2025-explained/ (Accessed: 30 May 2021).

Das, K., Gryseels, M., Sudhir, P. \& Tan, K. T. (2016) Unlocking Indonesia's digital opportunity, Jakarta: McKinsey\&Company.

Dekker, B., Okano-Heijmans, M. \& Zhang, E. (2020) Unpacking China's Digital Silk Road, s.l.: Clingendael Institute.

Ghiasy, R. \& Krishnamurthy, R. (2020) China's Digital Silk Road Strategic Implications for the EU and India. 
Ghiasy, R. \& Krishnamurthy, R. (2021) China's Digital Silk Road and the Global Digital Order (Online). Available at: https://thediplomat.com/2021/04/c hinas-digital-silk-road-and-the-globaldigital-order/ (Accessed: 31 May 2021).

Global Times. (2021) ASEAN becomes China's largest trading partner in 2020, with 7\% growth (Online). Available at: https://www.globaltimes.cn/page/20 2101/1212785.shtml\#: :text=ASEA $\mathrm{N} \% 20$ countries $\% 20$ have $\% 20$ jumped $\% 20$ to,partner $\% 20$ for $\% 20$ the $\% 20$ first \%20time (Accessed: 31 May 2021).

Hakim, A. (2020) Indonesia's digital payment providers OVO, Dana agree to merge Bloomberg (Online). Available at: https://www.spglobal.com/marketint elligence/en/news-insights/latestnews-headlines/indonesia-s-digitalpayment-providers-ovo-dana-agreeto-merge-8211-bloomberg-59042762 (Accessed: 1 June 2021).

Iswanto, D. (2021) Dub! 90 Persen Produk di E-commerce Barang Impor, Produk. UMKM Kita Kemana? (Online). Available at: https://akurat.co/duh90-persen-produk-di-e-commercebarang-impor-produk-umkm-kitakemana (Accessed: 4 June 2021).

J.P. Morgan. (2019) E-commerce Payments Trends: Indonesia (Online). Available at: https://www.jpmorgan.com/europe/ merchantservices/insights/reports/indonesia (Accessed: 28 May 2021).

Kemp, S. (2021) Digital 2021: Indonesia (Online). Available at: https://datareportal.com/reports/digi tal-2021-indonesia (Accessed: 2 June 2021).

Kusuma, H. (2020) Google Kini Kuasai 1,6\% Sabam di Tokopedia (Online). Available at: https://finance.detik.com/beritaekonomi-bisnis/d-5257317/google- kini-kuasai-16-saham-di-tokopedia (Accessed: 1 June 2021).

Lazanyuk, I. \& Revinova, S. (2019) Digital economy in the BRICS countries: Myth or reality?. International scientific and practical conference on digital economy (ISCDE 2019), pp. 1-20.

LY, B. (2020) "Challenge and perspective for Digital Silk Road”. Cogent Business \& Management, 7(1), pp. 1-19.

Milner, H. \&. K. K. (2005) "Why the Move to Free Trade? Democracy and Trade Policy in the Developing Countries". International Organization, 59(1), p. 107 143.

Morgan, E. C. (2002) "Perspective, Globalization and Human Security: A Neo-Gramscian". International Journal of Peace Studies, Volume 2, pp. 57-73.

Myovella, G., Karacuka, M. \& Haucap, J. (2020) "Digitalization and economic growth: A comparative analysis of Sub-Saharan Africa and OECD Economies". Telecommunications Policy, 44(2).

Pangestu, M. (2019) Lecture: Digital Economy and Development: an ASEAN Perspective (Online). Available at: https://www.youtube.com/watch?v= gjrx89sKpRA (Accessed: 2 June 2021).

Patria, N. \& Arief, A. (1999) Antonio Gramsci Negara \& Hegemoni. Yogyakarta: Pustaka Pelajar Offset.

Pointe Bello (2019) The Digital Silk Road Initiative: Wiring Global IT and Telecommunications to Advance Beijing's Global Ambitions. Pointe Bello.

Rakhmat, M. Z. \& Purnama, Y. (2021) For Indonesia, Chinese $5 G$ Cooperation Brings Promise and Peril (Online). Available at: https:/ / thediplomat.com/2021/01/fo r-indonesia-chinese-5g-cooperationbrings-promise-and-peril/ (Accessed: 2 June 2021). 
Rusakova, O. F., Gribovod, E. G. \&

Vakhrusheva, E. A. (2020)

Digitalization As a Growth Factor of "Soft Power" in the Context of Globalization. s.l., KnE Social Sciences, pp. 777-784.

Statista. (2021) Digital Market Outlook

(Online). Available at:

https://www.statista.com/outlook/d mo/ecommerce/indonesia

(Accessed: 28 May 2021).

Stec, G. (2018) The Invisible Silk Road:

Enter the Digital Dragon. EU-Asia at a Glance, May.

Suleiman, A. (2019) Chinese Investments in Indonesia's Fintech Sector: Their Interaction with Indonesia's Evolving Regulatory Governance, Jakarta: Center for Indonesian Policy Studies.

The ASEAN Post. (2019) Are ASEAN's Internet Speeds World Class? (Online). Available at: https://theaseanpost.com/article/areaseans-internet-speeds-world-class (Accessed: 1 June 2021).

Tiberghien, Y. (2020) For the Global Economy, US-China Rivalry Does Not Have to Mean Destruction (Online). Available at: https://www.globalasia.org/v15no2/ cover/for-the-global-economy-uschina-rivalry-does-not-have-to-meandestruction_yves-tiberghien (Accessed: 1 June 2021).
Widiartanto, Y. H. (2017) Jack Ma Resmi Jadi Penasibat E-commerce Indonesia (Online). Available at: https://tekno.kompas.com/read/201 7/08/23/09063567/jack-ma-resmijadi-penasihat-e-commerceindonesia\#: : :text=KOMPAS.com $\% 2$ $0 \% 2 \mathrm{D} \% 20$ Pendiri $\% 20$ sekaligus $\% 20 \mathrm{E}$ xecutive,committee $\% 20$ roadmap $\% 20$ e $\% 2$ Dcommerce $\% 20$ Indonesia. (Accessed: 4 June 2021).

Woolcock, J. A. (1985) "Politics, Ideology and Hegemony in Gramsci's Theory". Social and Economic Studies, September, 34(3), pp. 199-210.

Yuniar, R. W. (2020) Is Indonesia becoming too reliant on Huawei? (Online).

Available at: https://www.scmp.com/weekasia/economics/article/3112634/indo nesia-becoming-too-reliant-huawei (Accessed: 3 June 2021). 